\title{
Mikrobiyal gübre uygulamalarının Lolium perenne L. türünün çim performansı üzerine etkileri
}

\section{The effects of microbial fertilizers on turfgrass performance of Lolium perenne L.}

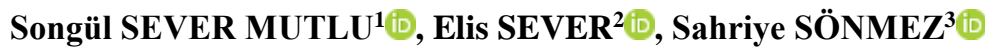

${ }^{1}$ Akdeniz Üniversitesi, Ziraat Fakültesi, Bahçe Bitkileri Bölümü, 07070 Antalya

${ }^{2}$ Akdeniz Üniversitesi, Mimarlık Fakültesi, Peyzaj Mimarlığı Bölümü, 07070 Antalya

${ }^{3}$ Akdeniz Üniversitesi, Ziraat Fakültesi, Toprak Bilimi ve Bitki Besleme Bölümü, 07070 Antalya

Sorumlu yazar (Corresponding author): S. Sever Mutlu, e-posta (e-mail): songulmutlu@ akdeniz.edu.tr

Yazar(lar) e-posta (Author e-mail): elissever@ hotmail.com, ssonmez@ akdeniz.edu.tr

\section{MAKALE BILLGISİ}

Alınış tarihi 12 Mart 2019

Düzeltilme tarihi 19 Nisan 2019

Kabul tarihi 26 Nisan 2019

\section{Anahtar Kelimeler:}

Çim alanlar

İngiliz çimi

Bacillus megaterium

Pantoea Agglomerans

Pseudomonas fluorenscens

\begin{abstract}
ÖZ
Bitki büyüme ve gelişmesini destekleyen mikroorganizmaları içeren mikrobiyal gübreler, kimyasal gübrelere olan ihtiyacı azaltabilmektedir. Mikrobiyal gübrelerin çim bitkilerine etkileri ve sürdürülebilir yeşil alanların yönetiminde kullanımına yönelik çalışmalar ise oldukça sınırlıdır. $\mathrm{Bu}$ çalısmanın amacı; Bacillus megaterium, Pantoea agglomerans ve Pseudomonas fluorenscens bakterilerini içeren mikrobiyal gübrenin (MG) çim alanlarda konvansiyonel gübrelere alternatif olarak kullanılabilme potansiyelini araştırmaktır. Denemede üç farklı doz MG $\left(100 \mathrm{ml} \mathrm{m}^{-2}, 1000\right.$ $\mathrm{ml} \mathrm{m}^{-2}$ ve $2000 \mathrm{ml} \mathrm{m}^{-2}$ ) ve konvansiyonel gübreleme programı altında Lolium perenne 'Blackcat'çeşidinin alanda tesis olma hızı, çim kalitesi, rengi, yoğunluğu, biçim artıkları verimi, kök ve sürgün ağırlı̆ı̆ herhangi bir gübreleme yapılmayan kontrol uygulaması ile karşılaştırılmıştır. Calısma 2013-2014 yıllarında Antalya'da tesadüf blokları deneme desenine göre 3 tekerrürlü olarak yürütülmüștür. Konvansiyel gübre uygulamasında net $10 \mathrm{~g} \mathrm{~m}^{-2} \mathrm{yl}^{-1}\left(100 \mathrm{~kg} \mathrm{~N}^{-1} 1 \mathrm{yl}^{-1}\right)$ dozunda azot uygulaması yapılmıștı. MG ve konvansiyonel gübre uygulamaları tohum ekim zamanı (Ekim), Sonbahar (Kasım) ve ilkbahar (Mart) olmak üzere 3 dönemde uygulanmıștır. MG uygulamalarının tamamı L. perenne türünün tesis olma hızını, çim kalite ve rengini, çim indeks değerini, çim yoğunluğunu ve kök sürgün ${ }^{-1}$ oranını kontrole göre arttırmıştır. Genel olarak MG uygulamaları arttıkça genel çim performansında artış gözlemlenmiștir. MG $2000 \mathrm{ml} \mathrm{m}^{-2}$ uygulaması azot uygulamasına eșdeğer tesis olma hızı olușturmuș ve ilkbaharda \%23 daha fazla sürgün yoğunluğu ile azot parsellerine üstünlük sağlamıştır. Konvansiyonel $\mathrm{N}$ gübreleme uygulamasına göre MG uygulamalarının biçim artıklarını önemli ölçüde azaltırken (dolayısıyla biçim sayısını azaltırken), kabül edilebilir bir çim kalitesi sağladıkları tespit edilmiştir. Çalışmadan elde edilen sonuçlar mikrobiyal gübrelerin $L$. perenne türünün sürdürülebilir çim alan yönetiminde önemli bir potansiyele sahip olabileceğini göstermiştir.
\end{abstract}

\section{ARTICLE INFO}

Received 12 March 2019

Received in revised form 19 April 2019

Accepted 26 April 2019

Keywords:

Turf Areas

Perennial ryegrass

Bacillus megaterium

Pantoea agglomerans

Pseudomonas fluorenscens

\begin{abstract}
Microbial fertilizers having plant growth promoting microorganisms might reduce the need for chemical fertilizers. There is a limited information available regarding the effect of microbia fertilizers on turfgrass species and possibility of their usage in the sustainable management of turf areas. The objective of this study was to study effectiveness of the microbial fertilizer (MF) consisting of Bacillus megaterium (KBA-10), Pantoea agglomerans RK-124 and Pseudomonas fluorenscens FDG-13 species on turf areas as an alternative to the conventional fertilizers. Turfgrass establishment rate, quality and color, density, clipping yield, root and shoot dry weight of Lolium perenne 'blackcat' fertilized with either 3 different dosage of MF or conventional fertilizer program were compared with untreated control. The study was conducted in Antalya during 2013-2014 and experimental design was randomized complete block with 3 replications. Under conventional fertilizer program net $10 \mathrm{~g} \mathrm{~N} \mathrm{~m}^{-2}$ year $^{-1}\left(100 \mathrm{~kg} \mathrm{~N} \mathrm{ha}^{-1}\right)$ was applied annually. Fertilizers were applied as three split application; at the seeding (October), fall (November) and spring (March). Microbial fertilizers enhanced turfgrass quality, color, density, grass index and root to shoot ratio compared to untreated control. Turf performance of $L$. perenne enhanced with the increased dosage of MF. Results showed that $2000 \mathrm{ml} \mathrm{m}^{-2}$ MF application provided turfgrass establishment similar to that of $\mathrm{N}$ and was superior to $\mathrm{N}$ for having $23 \%$ more shoot density. All of the MF dosages provided acceptable quality with less clipping yield compared to that of $\mathrm{N}$ application. Results support the important potential of microbial fertilizers as part of sustainable management of L. perenne.
\end{abstract}




\section{Giriş}

İngiliz çimi olarak bilinen Lolium perenne dünyada en yaygın kullanılan serin iklim çim türüdür. Özellikle serin-nemli yazlara sahip bölgelere iyi adapte olmuş $L$. perenne ülkemizde ev bahçelerinden parklara, futbol sahalarından golf sahalarına kadar çok farklı amaçlara hizmet eden yeşil alanların hakim çim türüdür. Sicak iklim bölgelerinde ise kışın yeşil çim örtüsünü devam ettirmek amaciyla sıcak iklim çim bitkisi ile oluşturulmuş yeşil alanlarda üst ekim amacıyla yaygın olarak kullanılmaktadır.

Yoğun kullanılan ve yüksek çim kalitesinin sağlanmasını temel alan yeşil alanlar başta azot olmak üzere kimyasal gübrelerin kullanımını gerektirmektedir. Azot, çim bitkilerinin en yüksek oranda ihtiyaç duyduğu ve gübreleme programında en fazla kullanilan temel besin elementidir (Emmons 2000). Çim bitkilerinin sürgün sıklı̆̆ını, rengini, sürgün ve kök gelişimini, farklı stres koşullarına dayanımını ve başta basılma ve çiğnenme zararı olmak üzere stres sonrası kendini yenileme yeteneğini etkilemesi nedeniyle gübreleme programlarının anahtar besin elementidir (Beard 1973). Azot uygulamasına oldukça hızlı ve iyi cevap veren $L$. Perenne türünde önerilen y1llık doz ev bahçeleri ve parklar için $50-100 \mathrm{~kg} \mathrm{~N} \mathrm{ha}^{-1}$ iken bu oran yoğun kullanılan futbol sahalarında $250 \mathrm{~kg} \mathrm{~N} \mathrm{ha}^{-1}$ a $\mathrm{a}$ kadar çıkabilmektedir (Puhalla ve ark. 2010). Sicak iklim bölgelerinde L. perenne çim türü ile üst ekimin yapıldığı spor sahalarında ise kullanılan $\mathrm{N}$ oranı yıllık $500 \mathrm{~kg} \mathrm{~N} \mathrm{ha}{ }^{-1}$ 'a ulaşabilmektedir (Puhalla ve ark. 2010). Bu durum ise sadece maliyet açısından değil, dikkatli uygulanmadığında çevresel açıdan da sorunlara neden olabilmektedir (Flipse ve ark. 1984). Yüksek miktarlarda kullanılan azot zamanlama ve teknik açıdan da yanlış uygulamalarla bir araya geldiğinde yıkanarak yüzey sularına veya yeraltı su kaynaklarına karışmaktadır (Beard 1973; Nektarios ve ark. 2014). Araştırmalar azot uygulaması ardından çim alanlardan sızan nitrat $\left(\mathrm{NO}_{3}{ }^{-}\right)$oranının bazı koşullarda (suda çözünen azot formunun tek seferde ve $5 \mathrm{~g} \mathrm{~N} \mathrm{~m}^{-2}$ den daha fazla uygulanması halinde) USEPA (Amerika Birleşik Devletleri Çevre Koruma Ajansı) tarafindan $10 \mathrm{mg} \mathrm{NO}_{3}{ }^{-} \mathrm{N}^{-1}$ olarak belirlenen üst sınırı geçerek risk oluş̧urduğuna dikkat çekmiştir (Miltner ve ark. 1996; Liu ve ark. 1997; Guillard ve Kopp 2004; Paulino-Paulino 2008). Kimyasal gübrelerin yoğun kullanımı bitki- mikroorganizma arasındaki doğal dengeyi ve toprak yapısını da olumsuz yönde etkileyerek biyolojik dengenin bozulmasına neden olmaktadır (Vessey 2003). Günümüzde gübreler dahil aşırı kimyasal kullanımı önemli bir problem olarak görülmekte ve hükümetler düzeyinde tedbirler alınmaya çalışılmaktadır (EEA 2009; EU 2009). Çevresel etkinin minimum seviye çekilmesi, mevcut kaynakların (su, gübre, enerji) etkin kullanımı ve bakım masraflarının azaltılmasını sağlayacak sürdürülebilir çim alan yönetimine olan ilgi bu bakımdan her geçen gün artmaktadır (Strandberg ve ark. 2012; Aamlid ve ark. 2014).

Mikrobiyal gübreler toprak verimliliğinin ve bitki performansının arttırılması ve çevre üzerindeki baskının azaltılması amacıyla sürdürülebilir tarımda kimyasal gübrelere önemli bir alternatif olarak gösterilmektedir (Reddy 2013; Javorekova ve ark. 2015). Biyogübreler olarak da isimlendirilebilen mikrobiyal gübreler, bitki için gerekli olan besin elementlerinin teminini veya biyolojik yolla yarayışlı hale gelmesini sağlayarak, bitkisel hormonları üreterek ve zararlı bazı patojenleri kontrol ederek bitki büyüme ve gelişimine katkıda bulunan canlı mikroorganizmaların ticari formulasyonlarıdır (Li ve Zhang 2008; Parlak ve Güner 2017). Bitki büyümesini teşvik edici bakteriler olarak isimlendirilen bu mikroorganizmalar tohum, bitki yüzeyi veya toprağa uygulandiktan sonra rizosfer bölgesini sararlar veya bitki dokusuna girerek konukçu bitki üzerinde etkilerini gösterirler (Vessey 2003; Li ve ark. 2016). Faydalı bu bakteriler bitki metabolizmasını direkt etkileyerek çimlenmeyi, büyüme ve gelişmeyi artırmaları sonucu verimde artış sağlayarak bitkiye doğrudan fayda sağlarlar veya hastalıkları önleme ve/veya seyrini azaltabilme yeteneğine ile bitki gelişimine dolaylı fayda sağlarken daha az pestisit kullanımına imkan verirler (Ping ve Boland 2004).

Bacillus megaterium, Pantoea agglomerans ve Pseudomonas fluorenscens bakterileri üzerinde en çok araştırma yapılan ve tarımda geniş kullanım potansiyeline sahip faydalı mikroorganizmalar arasindadır (Jayaswal ve ark. 1993; Çakmakçi ve ark. 1999; Ryu ve ark. 2004; Li ve Zhang 2008). Ürettikleri farklı asitler ile inorganik fosfatı çözerek bitkiye alınabilirliğini arttıran ve siderofor sentezi yoluyla alınamaz formdaki demiri şelatlayarak demirin bitkiye alınabilmesini sağlayan, farklı stres koşullarına karşı bitkiye dayanıklılık veren, antimikrobiyal metobolitler üreterek kök bölgesindeki patojenik bakterileri baskılayabilen ve bitki büyüme hormonlarını sentezleyebilme özelliği ile bilinen $B$. megaterim ve $P$. fluorenscens mikrogübreler içinde önemli yer bulmaktadır (Bloemberg ve Lugtenberg 2001; Castanheira ve ark. 2013; Li ve ark. 2016). Mikrobiyal gübreler içinde yaygın kullanılan bir diğer bakteri $P$. agglomerans' 'ın; ürettiği oksin (IAA), sitokinin, giberelik asit gibi fito hormonlar ile misır, arpa, buğday ve pirinç gibi monokot bitkilerde büyümeyi teşvik ettiği ve azot içermeyen ortamda verimi arttırdığı kanıtlanmıştır (Zahir ve ark. 2001; Feng ve ark. 2006; Castanheira ve ark. 2013; Li ve ark. 2016). Ayrıca $P$. agglomerans türünün konukçu bitkisinde Erwinia amylovora, Botrytis cinerea, Penicillium expansum gibi patojenlerin sebeb olduğu hastalıklara karşı mükemmel koruma sağladığı kanıtlanmıştır (Nunes ve ark. 2002).

$\mathrm{Bu}$ çalışmalardan elde edilen sonuçlar belirtilen bu bakterilerin test edildikleri bitkilerde verimi ve kaliteyi arttırdığına işaret ederek tarımsal amaçlı kimyasallarının kullanımının azaltılması ve yetişme ortamında biyolojik çeşitliliğinin sürdürülmesinde önemli potansiyellerini ortaya koymaktadır (Kloepper ve ark. 1992; Feng ve ark. 2006). Ancak bahsedilen bu araştırmaların neredeyse tamamı başta arpa, buğday, pirinç ve mısır olmak üzere çim bitkileri dışındaki bitki türlerinde yürütülmüştür. Mikrobiyal gübrelerin çim bitkilerinin performansı ve yeşil alanlarda kullanılabilme potansiyeli konusunda yapılan çalışmalar kısıtlı olup sonuçlar uyum içinde değildir (Castanheira ve ark. 2013; Kuo 2015). Açıkgoz ve ark. (2016) Bacillus subtilis ve B. megaterium uygulamalarının $L$. perenne ve Festuca arundinaceae çim türlerinde çim rengi ve biçim artıkları verimi üzerine az oranda da olsa pozitif etki sağladığı için azotlu gübreye olan ihtiyacı azaltabileceğini ve gübreleme programına entegre edilebileceklerini bildirmişlerdir. Kuo (2015) sera koşullarında büyütülen bermuda çiminde (Cynodon dactylon) azot bağlayabilen ve fosfor çözebilen bakterileri içeren (Rhizobium, Azotobacter, Cyanobacteria, Rhizobacteria ve pseudomonas) mikrobiyal gübre uygulamasının konvansiyonel gübre uygulamasına eşdeğer performans gösterdiğini bildirmiştir. Öte yandan Peacock ve Daniel (1992) ise F. arundinaceae ve C. dactylon çim türlerinde organik gübreye ilave edilen Bacillus spp. uygulamasının konvansiyonel azotlu gübrelemeye göre bitki büyüme ve gelişmesini artırmadığını bildirmişlerdir.

Mikrobiyal gübrelerin çim bitkileri üzerindeki etkilerini anlayabilmek, başta azot olmak üzere kimyasal gübrelere olan 
ihtiyacı azaltabilmek ve dolayısıyla yeşil alanlarda sürdürülebilir bakım programının geliştirilmesi için elzemdir. $\mathrm{Bu}$ çalışmanın amacı üç farklı bakteri türünü içeren mikrobiyal gübrenin $L$. perenne çim türünün arazi koşullarında çim performansı üzerine etkilerini standart (konvansiyonel) gübreleme ile karşılaştırarak çim alanlarda kullanım olanaklarını belirlemektir.

\section{Materyal ve Yöntem}

Araştırma Akdeniz Üniversitesi Ziraat Fakültesi Araştırma ve Uygulama arazisinde 2013-2014 yılları arasında yürütülmüştür. Çalışma her biri $1 \mathrm{~m}^{2}$ büyüklüğünde hazırlanan deneme parsellerinde tesadüf blokları deneme deseninde ve 3 tekerrürlü olarak yürütülmüştür. Parseller arasında $1 \mathrm{~m}$ boşluk bırakılmıştır. Ekim öncesi toprak havalandırılmış, yabancı otlarından arındırılmış, tesviyesi yapılarak ekime hazır hale getirilmiştir. L. perenne 'Blackcat' çeşidi tohumları $30 \mathrm{~g} \mathrm{~m}^{-2}$ oranında 22 Ekim 2013 tarihinde ekilmiştir. Bacillus megaterium KBA-10, Pantoea agglomerans RK-124, ve Pseudomonas fluorenscens FDG-137 bakterilerini içeren mikrobiyal gübre (BM-Mega flu) 3 farklı dozda $\left(100 \mathrm{ml} \mathrm{m}^{-2}\right.$, $1000 \mathrm{ml} \mathrm{m}^{-2}$ ve $2000 \mathrm{ml} \mathrm{m}^{-2}$ ) uygulanarak etkileri konvansiyonel azotlu gübre ve gübreleme uygulaması yapılmayan kontrol uygulamaları ile karşılaştırılmıştır. Deneme; 3 farklı doz mikrobiyal gübre uygulaması, konvansiyonel ve kontrol uygulamaları olmak üzere toplam 15 parselde yürütülmüştür. Kullanılan mikrobiyal gübrenin üretici firma tarafından garanti edilen içeriğinin pH's1 5.7-7.7 ve toplam canlı mikroorganizma sayıs1: $2.1 \times 108 \mathrm{cfu} \mathrm{ml}^{-1}$ (colony forming units) dir. Belirlenen her bir doz için mikrobiyal gübre 101 klorsuz su içinde karıştırılarak 1 gün bekletilmiş ve sırt pompası ile 3.3 $1 \mathrm{~m}^{-2}$ oranında kalibrasyonu yapılarak ilgili parsellere uygulanmıştır. Konvansiyonel azot uygulamasında, parsellere net $5 \mathrm{~g} \mathrm{~m}^{-2}$ azot düşecek şekilde ekimle birlikte 15-15-15 kompoze gübre verilmiştir. Tekrar doz uygulamalarında ekimden 4 hafta (20 Kasim 2013) ve 18 hafta sonra (1 Mart 2014) ise; mikrobiyal gübre parsellerine aynı dozlarda, azot parsellerine ise net $2.5 \mathrm{~g} \mathrm{~m}^{-2}$ azot düşecek şekilde amonyum sülfat gübresi verilmiştir. Kontrol olarak oluşturulan çim parsellerine ise herhangi bir gübre uygulaması yapılmamıştır. Serin iklim çim türlerinde konvansiyonel gübreleme programında ev bahçeleri ve parklarda kabul edilebilir çim kalitesini sağlamak üzere Ekim, Kasım ve Mart aylarında (ihtiyaca göre belki Nisan-Mayıs) her bir uygulamada $\mathrm{m}^{2}$ ye net 2.5-5 g azot verilmesi tavsiye edilen standart bir uygulamadir (Emmons 2000; Beard 1973). Ekimin ardından tohumların üzeri $5 \mathrm{~mm}$ ince bir torf tabakası ile örtülmüş ve tohum-toprak temasını sağlamak için silindirlenmiştir. Ekim sonrası alandaki mevcut yağmurlama sulama sistemi kullanılarak tohumların çimlenmeleri ve strese girmeden büyüme ve gelişmelerini sürdürmeleri temin edilmiştir. Çimler biçim olgunluğuna geldiklerinden itibaren (ekimden sonra 6 . hafta) aktif büyüme dönemleri boyunca biçim artıklarını toplayan üniteye sahip rotary tip çim biçme makinesi (Hasquvarna Lc253S) ile $4 \mathrm{~cm}$ yükseklikten düzenli biçilmiştir. Çalışma süresince yabancı otlar el ile alınmış ve parsellere pestisit uygulaması yapılmamıştır. Denemenin yürütüldüğü alanda toprak killi tınlı yapıda (\%37 Kum, \%34 Kil, \%29 Silt), yüksek pH'lı (8.7), tuzsuz $(\mathrm{EC}=228 \mu \mathrm{mhos} / \mathrm{cm})$, çok kireçli $(\% 29.7)$ olup; ayrıca toprak $31 \mathrm{mg} \mathrm{kg}^{-1} \mathrm{P}$ (Olsen), $407 \mathrm{mg} \mathrm{kg}^{-1} \mathrm{~K}$ (Carson 1980), $5150 \mathrm{mg} \mathrm{kg}^{-1} \mathrm{Ca}, 337 \mathrm{mg} \mathrm{kg}{ }^{-1} \mathrm{Mg}$ ve $\% 1.6$ organik madde içeriğine sahiptir.

\subsection{Alınan gözlem ve ölçümler}

Mikrobiyal gübre ve konvansiyonel (azot) uygulamalarının tohum ekiminden itibaren $L$. perenne türünün çim performansı üzerine etkilerini belirlemek amaciyla tesis olma (alan kaplama) oranı, çim kalitesi ve rengi, çim indeks değeri, klorofil içeriği, çim yoğunluğu, biçim artıkları verimi, kök, sürgün ve toplam biyokütle kuru ağırlıkları belirlenmiş ve alınan yaprak örneklerinin bitki besin elementi içerikleri belirlenmiştir. Tesis olma hızı, görsel olarak tohum ekiminden sonra çim bitkisi ile kaplı alanın yüzde (\%) olarak değerlendirilmesi olup iki haftada bir değerlendirilmiştir. Çim kalitesi 15 günde bir görsel 1-9 kalite puanlama skalası kullanılarak değerlendirilmiştir. $\mathrm{Bu}$ skalada $1=$ tamamen ölü /sarı çim dokusu ile çok kötü, $6.0=$ kabul edilebilir minimum çim kalitesini, 9.0= ideal sürgün yoğunluğu doku, yeşil renk ve homojenlik ile mükemmel kaliteyi temsil etmektedir. İki haftada bir alınan genel çim rengi bitkinin genetik renginin değil, parsel renginin bir bütün olarak değerlendirilmesi olup 1-9 renk skalası kullanılarak değerlendirilmiştir. Bu skalada 1.0 değeri tamamen sararmayı (sarı rengi). 6.0 değeri açık yeşil ve 9.0 değeri koyu yeşil rengi ifade etmektedir. Görsel alınan çim kalitesine ek olarak çim indeks değeri TCM 500 "NDVI" Turf Color Meter ile on beş günde bir her parselden on beş adet okuma yapılarak ölçülmüştür. Belirtilen bu alet okunan alandaki $660 \mathrm{~nm}$ ve $840 \mathrm{~nm}$ dalga boyundaki 1 şı ğ kullanarak normalize edilmiş vejetasyon indeks değerlerini (NDVI) hesaplamakta ve bu değerleri kullanarak 1-9 arasında çim indeks değerlerine dönüştürmektedir. $\mathrm{Bu}$ skalada $1=$ en kötü çim kalitesi olup (ölü/sarı çim örtüsü). 9 değeri en yüksek çim kalitesine eşdeğerdir. Klorofil ölçümleri (göreceli klorofil içeriği değerleri) klorofil metre (FIELDSCOUT CM 1000) kullanılarak sonbaharda iki haftada bir her parselden 15 adet okuma yapılarak alınmıştır. İki haftada bir alınan kalite, renk, çim indeks ve klorofil verileri mevsimlere göre birleştirilerek analiz edilmiştir. Çim yoğunluğu sonbahar (27 Kasım 2013) ve ilkbahar (15 Mayıs 2014) olmak üzere iki defa belirlenmiştir. $\mathrm{Bu}$ amaçla her bir parselden tesadüfü seçilen 2 noktadan $10 \mathrm{~cm}$ çapındaki toprak profil örnekleyici ile örnekler çıkarılmış, içindeki toplam sürgün sayısı belirlenmiş ve ardından yerine geri yerleştirilmiştir. Biçim artıkları verimi ise her bir biçim sonrası (toplam 6 biçim) toplanan biçim artıklarının kağıt zarflara konarak $72^{\circ} \mathrm{C}$ de 48 saat kurutulduktan sonra kuru ağırlıklarının tartılması ile belirlenmiştir. Her bir uygulama konusu için deneme süresince elde edilen tüm veriler birleştirilerek analiz edilmiştir. Kök ve sürgün kuru ağırlığ denemenin sonlandırıldığı tarihte belirlenmiştir. Her parselden tesadüfü seçilen 2 noktadan $10 \mathrm{~cm}$ çapındaki çim profil örnekleme aleti ile çıkarılan çim blokları 2 saat kadar suda bekletildikten sonra basınçlı su ile yıkanarak topraklarından arındırılmıştır. Yıkama işlemi ardından 24 saat suların süzülmesi için beklendikten sonra bitkinin toprak üst aksamı (sürgün kısmı) kök kısmından makasla kesilerek ayrılmış ve zarflara konarak yaş ağırlıkları alındıktan sonra $72^{\circ} \mathrm{C}$ de 48 saat kurutularak kuru ağırlıkları belirlenmiştir. Yaprak örneklerinin besin element içeriklerini belirlemek amacıyla; Ekim ve Mart aylarında yapılan gübreleme uygulamalarından 5 hafta sonra yaprak örnekleri alınmıştır. Alınan yaprak örneklerinin N içeriği modifiye Kjeldahl metoduna göre; diğer bitki besin elementleri (P, K, Ca, Mg, Fe, Mn, Zn ve $\mathrm{Cu}$ ) içeriği nitrik-perklorik asit karışımı ile yaş yakılarak elde edilen süzükte ICP-OES (Perkin Elmer-Inductively Coupled Plasma) kullanılarak belirlenmiştir (Kacar ve İnal 2008). 
Arazi gözlemlerinden alınan tüm veriler PROC (SAS Institute 1999) programı ile varyans analiz yöntemi yöntemi kullanılarak analiz edilmiştir. Ortalamalar Fisher metoduna göre korunmuş en az önemli fark (LSD) testi ile karşılaştırılmış ve faktörler düzeyinde $\operatorname{LSD}_{(0.05)}$ değerleri hesaplanmıştır.

\section{Bulgular ve Tartışma}

L. perenne türünün genel çim performansı üzerine $\mathrm{MG}$ ve azot gübrelemesi uygulamalarının etkileri Çizelge 1-4 de verilmiştir. Yapılan istatistik analizleri sonucunda tesis olma hızı, kalite, renk, çim indeks, klorofil içeriği ve biçim artıkları, kök, sürgün ve toplam biyokütle kuru ağırlıkları açısından gübre uygulamaları arasındaki farklar istatistiksel olarak önemli bulunmuştur. Mikrobiyal gübre ve $\mathrm{N}$ uygulamasının her ikiside kontrole göre çimin alanda tesis olma hızını arttırmıştır (Çizelge 1). Büyümeyi teşvik eden bakterilerin bitki gelişimi üzerine positif etkisini gösteren ilk indikatörlerden birisi tohum çimlenme oranı/ çıkışında artış ve bitkinin alanda yerleşebilmesidir (Kloepper ve ark. 1986; Parveen ve ark. 2018). MG uygulamalarında doz artışına bağlı olarak çimin tesis olma oranının arttığı ve $2000 \mathrm{ml}$ MG ile N uygulaması arasında ise istatistiki olarak önemli bir fark olmadığı tespit edilmiştir. Nitekim tohum ekildikten 4 hafta sonra, kontrol uygulamasında sadece $\% 70$ olan çim ile kaplı alan oran $1 \mathrm{~N}$ ve $2000 \mathrm{ml}$ MG uygulamalarında sirasiyla \%95 ve \%93'e ulaşmıştır. Mikrobiyal gübrenin çimlenmeyi arttırıcı etkisi, içerdiği bakterilerin giberellik asit ve sitokinin gibi çimlenmeyi kontrol eden bitkisel hormonları üretebilme veya modifiye edebilme yeteneğine bağlanabilir (Butler 2006).

Sonbahar, kış ve ilkbahar dönemsel çim kalite ortalamaları incelendiğinde en yüksek ve en düşük çim kalitesi sırasıyla $\mathrm{N}$ ve kontrol uygulamaları ile elde edilmiştir (Çizelge 1). Kontrol parselleri hiçbir dönemde kabül edilebilir bir çim kalitesi olan 6.0 skala değerine ulaşamamıştır. Artan doza bağlı olarak

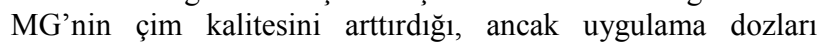
arasındaki farkların istatistiki olarak önemli olmadığ 1 belirlenmiştir. İlkbahar çim kalite değerleri incelendiğinde ortalama 7.2 skala değeriyle $\mathrm{N}$ parselleri en yüksek çim kalitesini sağlarken onu 6.7 ile istatistiki olarak farklı olmayan $2000 \mathrm{ml} \mathrm{MG}$ uygulaması izlemiştir. Aynı dönemde diğer MG uygulamaları ort. 6.4 skala değeriyle kabül edilebilir ve üstü çim kalitesi oluşturarak ortalama 5.5 olan kontrol parsellerini geride bırakmıştır.

Genel çim rengi açısından uygulamalar arasındaki farklar önemli bulunmuş ve beklendiği üzere $\mathrm{N}$ parselleri deneme süresince diğer uygulamalara göre daha koyu yeşil çim rengi sağlamıştır (Çizelge 1). Çime yeşil rengini veren klorofilin temel yapıtaşlarından biri olması nedeniyle bitki azot seviyesi ile çim rengi arasında direkt bir ilişki mevcuttur (Beard 1973). Renk çim bitkilerinde azotlu gübreleme zamanını belirlemek için sıklıkla kullanılan bir indikatör olup azot uygulaması sonrası kontrole göre daha koyu yeşil çim rengi diğer araştırmacılar tarafından da bildirilmiştir (Ledeboer ve Skogley 1973; Heckman ve ark. 2000; Miltner ve ark. 2004). MG dozları arasında çim rengi açısından önemli bir fark bulunmamıştır. Sonbahar da tohum ekiminden itibaren alanda tesis olma sürecinde MG uygulamaları ort. 6.0 renk skala değeri ile 7.0 renk skala değeri alan kontrol uygulamasına göre daha açık yeşil dokuda çim rengi göstermiştir. Kışın MG ve kontrol uygulamaları arasında çim rengi açısından önemli bir fark görülmezken ilkbaharda MG dozlarının tamamı kontrole göre daha yüksek renk skala değerleri alarak orta koyu yeşil renkte çim dokusu oluşturmuşlardır. Acikgoz ve ark. (2016) B. megaterium ve $B$. subtilis uygulamalarının $F$. arundianceae türünde çim rengini kontrole göre arttırırken. L. perennne türünde fark oluşturmadığını ancak azot ile birlikte uygulandıklarında istatistiki olarak artış sağladığını bildirmiştir. Çim indeks değerleri incelendiğinde sonuçların renk verileri ile uyum içinde olduğu ve $\mathrm{N}$ parsellerinin ortalama 6.8-6.2 skala değerleri ile incelenen tüm dönemlerde en iyi çim performansını sağladığı tespit edilmiştir (Çizelge 2). Kontrol ve MG uygulamaları sonbahar ve kış döneminde benzer çim indeks değerleri alırken, ilkbaharda MG uygulamaları kontrolden daha yüksek çim indeks değerleri ile daha iyi çim performans1 göstermiştir. Relatif klorofil indeks değerleri incelendiğinde; MG ve kontrol arasında önemli bir fark bulunmadığ 1 ve $N$ uygulanmış parsellerin istatistiki olarak daha yüksek klorofil içerdiği tespit edilmiştir (Çizelge 2). Kuo (2015) ise farklı bakterilerden oluşan MG uygulamasının bermuda çiminde klorofil miktarını kontrole göre 3 kat arttırdığını bildirmiştir.

Deneme süresince toplanan biçim artıklarının kuru ağırlık sonuçları incelendiğinde; uygulamalar arasındaki farkların önemli olduğu, en yüksek ve en düşük değerlerin sırasıyla N ve kontrol parsellerinden elde edildiği saptanmıştır (Çizelge 3). Nitekim kontrol parsellerinden biçilen çim miktarı toplamı ort. $41.9 \mathrm{~g} \mathrm{~m}^{-2}$ iken. $\mathrm{N}$ uygulaması bu miktarı $\% 479$ oranında arttırmıştır. MG uygulamaları ise biçilen çim miktarını kontrole göre \%93-111 oranında arttırmış ve dozlar arasındaki farklar ise istatistiksel olarak önemli bulunmamıştır. Azot ve $\mathrm{MG}$ gübre uygulamalarının biçim artıkları verimi üzerine etkileri Acikgoz ve ark. (2016)'nın sonuçları ile uyum içindedir. Nitekim araştırıcilar azot $\left(30 \mathrm{~g} \mathrm{~N} \mathrm{~m}^{-2} \mathrm{yil}^{-1}\right)$ ve $\mathrm{MG}$ (B. megaterium) uygulamalarının $L$. perenne'de biçim artıkları kuru verimini kontrole göre sirasıyla \%764 ve \%104 oranında arttırdığını tespit etmişlerdir. Azotun çim bitkilerinde biçim artıkları verimini bir başka deyişle üretilen sürgün miktarını artırıcı etkisi önceki çalışmalarda da rapor edilmiştir (Ledeboer ve Skogley 1973; Heckman ve ark. 2000). Genel olarak kullanılabilir azot miktarı arttıkça, çim bitkilerinde sürgünlerin büyüme ve gelişme hızı artmaktadır (Beard 1973). Stres sonrası kendini onarma gibi özel bazı durumlar dışında çim bitkilerinde sürgün büyümesini aşırı miktarda teşvik eden ve biçimi (biçim ile kesilecek yaprak miktarını) arttıran gübrelemeler enerji ve işgücünü arttırması nedeniyle arzu edilmemektedir (Heckman ve ark. 2000). Bu nedenle çim gübreleme programında temel amaç; kabül edilebilir genel çim kalitesi sağlanırken biçim artıkları miktarını minimize edebilmektir. $\mathrm{Bu}$ çalışmada kullanılan MG uygulamaları konvansiyonel $\mathrm{N}$ uygulamasına göre biçim artıklarını önemli ölçüde azaltırken (dolayısıyla biçim sayısını azaltırken) kabul edilebilir çim kalitesini sağlamıştır. Son yıllarda kentsel atık miktarlarının azaltılması ve yeniden değerlendirilmesi kapsamında çim alanlarda 'kes ve biçim artıklarını alana bırak' sloganı çevreci bir uygulama modeli olarak teşvik edilmeye çalışılmaktadır (Van Duyne 1994). Makul ölçülerde üretilen biçim artıklarının toplanmak yerine yüzey üzerine bırakılması ile besin elementlerinin önemli ölçüde geri kazanımı da sağlanmaktadır (Starr and DeReo 1981). Bu yaklaşımda temel şart biçim sonrası kesilen atık miktarının yani sürgün biyomasının fazla olmamasıdır. Nitekim alana bırakılan kalın bir tabaka hem estetik olarak kötü görünümlere neden olmakta hem de alttaki çim örtüsünün fotosentezini düşüreceğinden bitkiye zarar verebilmektedir (Turgeon 1998). Çalışmamızdan elde edilen sonuçlar; atık miktarını $\mathrm{N}$ uygulamasına göre önemli ölçüde baskılayan $\mathrm{MG}$ uygulamasının biçim artıklarının alanda bırakılması modeli için uygun bir aday olabileceğini göstermektedir. 
Çizelge 1. Azot $\left(10 \mathrm{~g} \mathrm{~N} \mathrm{~m}^{-2} \mathrm{yll}^{-1}\right)$, farklı dozlarda ( 100,1000 ve $\left.2000 \mathrm{ml} \mathrm{m}^{-2}\right)$ mikrobiyal gübre (MG) ve kontrol $\left(0 \mathrm{ml} \mathrm{m}^{-2} \mathrm{MG} \mathrm{ve} 0 \mathrm{~g} \mathrm{~N} \mathrm{~m}^{-2}\right)$ uygulamalarının Lolium perenne türünün alanda tesis olma oranı (tohum ekiminden 4 hafta sonra), dönemsel çim kalitesi ve rengi üzerine etkileri.

Table 1. Effects of nitrogen (10 $\mathrm{g} \mathrm{N} \mathrm{m}^{-2}$ year $\left.{ }^{-1}\right)$, microbial fertilizer (MF) at different doses (100, 1000 and $\left.2000 \mathrm{ml} \mathrm{m}^{-2}\right)$ and control treatments $(0 \mathrm{ml}$ $\mathrm{m}^{-2} \mathrm{MG}$ and $0 \mathrm{~g} \mathrm{~N} \mathrm{~m}^{-2}$ ) on establishment, turfgrass quality and color of Lolium perenne at four weeks after seeding.

\begin{tabular}{|c|c|c|c|c|c|c|c|}
\hline \multirow[b]{2}{*}{ Uygulamalar } & \multirow{2}{*}{$\frac{\text { Tesis olma }(\%)}{4 . \mathrm{Hafta}}$} & \multicolumn{3}{|c|}{$\begin{array}{c}\text { Genel Çim Kalitesi } \\
\text { (1-9 skalası; } 9=\text { mükemmel) }\end{array}$} & \multicolumn{3}{|c|}{$\begin{array}{c}\text { Çim Rengi } \\
\text { (1-9 skalası; } 1=\text { sarı, 9= koyu yeşil) }\end{array}$} \\
\hline & & Sonbahar & $\mathrm{K}_{1} s ̧$ & İlkbahar & Sonbahar & Kiş & İlkbahar \\
\hline Azot & $95 \mathrm{a}$ & $8.2 \mathrm{a}$ & $7.2 \mathrm{a}$ & $7.2 \mathrm{a}$ & $9.0 \mathrm{a}$ & $7.2 \mathrm{a}$ & $7.7 \mathrm{a}$ \\
\hline MG-100 & $88 \mathrm{~b}$ & $6.0 \mathrm{~b}$ & $5.0 \mathrm{~b}$ & $6.4 \mathrm{~b}$ & $6.0 \mathrm{c}$ & $5.4 \mathrm{~b}$ & $6.5 \mathrm{~b}$ \\
\hline MG-1000 & $89 \mathrm{~b}$ & $6.5 \mathrm{~b}$ & $5.0 \mathrm{~b}$ & $6.4 \mathrm{~b}$ & $6.0 \mathrm{c}$ & $5.4 \mathrm{~b}$ & $6.4 \mathrm{~b}$ \\
\hline MG-2000 & $93 \mathrm{ab}$ & $6.6 \mathrm{~b}$ & $5.0 \mathrm{~b}$ & $6.7 \mathrm{ab}$ & $5.8 \mathrm{c}$ & $5.3 \mathrm{~b}$ & $6.7 \mathrm{~b}$ \\
\hline Kontrol & $70 \mathrm{c}$ & $5.0 \mathrm{c}$ & $4.5 \mathrm{~b}$ & $5.5 \mathrm{c}$ & $7.0 \mathrm{~b}$ & $5.4 \mathrm{~b}$ & $5.9 \mathrm{c}$ \\
\hline Ort. & 87 & 6.5 & 5.3 & 6.4 & 6.8 & 5.7 & 6.6 \\
\hline Önemlilik Derecesi & $* *$ & $* *$ & $* * *$ & $*$ & $* * *$ & $* * *$ & $* * *$ \\
\hline
\end{tabular}

$\overline{\text { Aynı sütunda farklı harflerle gösterilen ortalamalar arasındaki fark önemlidir. }{ }^{*}, * *}$ ve ${ }^{* * *}$ sırasılyla $\mathrm{p} \leq 0.05, \mathrm{p} \leq 0.01$ ve $\mathrm{p} \leq 0.001$ düzeyinde önemli olduğunu ifade etmektedir.

Çizelge 2. Azot $\left(10 \mathrm{~g} \mathrm{~N} \mathrm{~m}^{-2} \mathrm{yl}^{-1}\right)$, farklı dozlarda (100, 1000 ve $\left.2000 \mathrm{ml} \mathrm{m}^{-2}\right)$ mikrobiyal gübre (MG) ve kontrol $\left(0 \mathrm{ml} \mathrm{m}^{-2} \mathrm{MG}\right.$ ve $\left.0 \mathrm{~g} \mathrm{~N} \mathrm{~m}^{-2}\right)$ uygulamalarının Lolium perenne türünün çim indeks değeri ve göreceli klorofil içeriği üzerine etkileri.

Table 2. Effects of nitrogen (10 $\mathrm{g} \mathrm{N} \mathrm{m}^{-2}$ year $\left.{ }^{-1}\right)$, microbial fertilizer (MF) at different doses (100, 1000 and $\left.2000 \mathrm{ml} \mathrm{m}^{-2}\right)$ and control treatments $(0 \mathrm{ml}$ $\mathrm{m}^{-2} \mathrm{MG}$ and $0 \mathrm{~g} \mathrm{~N} \mathrm{~m}^{-2}$ ) on grass index and relative chlorophyll content of Lolium perenne.

\begin{tabular}{|c|c|c|c|c|c|}
\hline \multirow[b]{2}{*}{ Uygulamalar } & \multicolumn{3}{|c|}{$\begin{array}{c}\text { Çim indeks değeri } \\
\text { 1-9 sakalası; 6= kabül edilebilir, } 9=\text { Mak. kalite) }\end{array}$} & \multicolumn{2}{|c|}{ Klorofil İçeriği } \\
\hline & Sonbahar & $\mathrm{K}_{1}$ Ş & İlkbahar & Sonbahar & $\mathrm{K}_{1 s ̧}$ \\
\hline Azot & $6.8 \mathrm{a}$ & $6.6 \mathrm{a}$ & $6.2 \mathrm{a}$ & $456 \mathrm{a}$ & $436 \mathrm{a}$ \\
\hline MG-100 & $6.6 \mathrm{~b}$ & $6.2 \mathrm{~b}$ & $5.9 \mathrm{~b}$ & $331 \mathrm{~b}$ & $270 \mathrm{~b}$ \\
\hline MG-1000 & $6.5 \mathrm{bc}$ & $6.2 \mathrm{~b}$ & $5.9 \mathrm{~b}$ & $313 \mathrm{~b}$ & $257 \mathrm{~b}$ \\
\hline MG-2000 & $6.5 \mathrm{bc}$ & $6.2 \mathrm{~b}$ & $6.0 \mathrm{~b}$ & $314 b$ & $256 \mathrm{~b}$ \\
\hline Kontrol & $6.4 \mathrm{c}$ & $6.0 \mathrm{~b}$ & $5.7 \mathrm{c}$ & $323 \mathrm{~b}$ & $266 \mathrm{~b}$ \\
\hline Ort. & 6.6 & 6.2 & 5.9 & 347 & 297 \\
\hline Önemlilik Derecesi & $* * *$ & $* * *$ & $* * *$ & $* *$ & $* * *$ \\
\hline
\end{tabular}

Aynı sütunda farklı harflerle gösterilen ortalamalar arasındaki fark önemlidir. ${ }^{*},{ }^{*}$ ve ${ }^{* * *}$ sırasıyla $\mathrm{p} \leq 0.05, \mathrm{p} \leq 0.01$ ve $\mathrm{p} \leq 0.001$ düzeyinde önemli olduğunu ifade etmektedir.

Çizelge 3. Azot $\left(10 \mathrm{~g} \mathrm{~N} \mathrm{~m}^{-2} \mathrm{yll}^{-1}\right)$, farklı dozlarda (100, 1000 ve $\left.2000 \mathrm{ml} \mathrm{m}^{-2}\right)$ mikrobiyal gübre (MG), ve kontrol $\left(0 \mathrm{ml} \mathrm{m}{ }^{-2} \mathrm{MG}\right.$ ve $\left.0 \mathrm{~g} \mathrm{~N} \mathrm{~m}^{-2}\right)$ uygulamalarının Lolium perenne türünün biçim artıkları, sürgün yoğunluğu, sürgün, kök ve toplam biyokütle kuru ağırlığı ve kök /sürgün oranı üzerine etkileri.

Table 3. Effects of nitrogen $\left(10 \mathrm{~g} \mathrm{~N} \mathrm{~m}^{-2}\right.$ year $\left.{ }^{-1}\right)$, microbial fertilizer (MF) at different doses (100, 1000 and $\left.2000 \mathrm{ml} \mathrm{m}^{-2}\right)$ and control treatments $\left(0 \mathrm{ml}^{2}\right.$ $\mathrm{m}^{-2} \mathrm{MG}$ and $0 \mathrm{~g} \mathrm{~N} \mathrm{~m}^{-2}$ ) on clipping yield, shoot density, dry weights of shoot, root and totol biomass and root to shoot ratio of Lolium perenne.

\begin{tabular}{|c|c|c|c|c|c|c|}
\hline \multirow[b]{3}{*}{ Uygulamalar } & \multirow{2}{*}{\multicolumn{2}{|c|}{ Biçim Artıkları Kuru Ağırlık }} & \multicolumn{4}{|c|}{ Sürgün yoğunluğu } \\
\hline & & & \multicolumn{2}{|c|}{ Sonbahar } & \multicolumn{2}{|c|}{ İlkbahar } \\
\hline & $\mathrm{g} \mathrm{m}^{-2}$ & Fark $(\%)$ & Adet $100 \mathrm{~cm}^{-2}$ & Fark $(\%)$ & Adet $100 \mathrm{~cm}^{-2}$ & Fark $(\%)$ \\
\hline Azot & $242.4 \mathrm{a}$ & +479 & $150 \mathrm{~b}$ & +1 & $241 \mathrm{~b}$ & 25 \\
\hline MG-100 & $81.4 \mathrm{~b}$ & +94 & $166 \mathrm{a}$ & 13 & $243 \mathrm{~b}$ & 26 \\
\hline MG-1000 & $80.9 \mathrm{~b}$ & +93 & $160 \mathrm{ab}$ & 8 & $248 \mathrm{~b}$ & 28 \\
\hline MG-2000 & $88.4 \mathrm{~b}$ & +111 & $165 \mathrm{a}$ & 11 & $296 \mathrm{a}$ & 53 \\
\hline Kontrol & $41.9 \mathrm{c}$ & --- & $148 \mathrm{~b}$ & -- & $193 \mathrm{c}$ & -- \\
\hline Ort. & 107.0 & & 157 & & 244 & \\
\hline Önemlilik derecesi & $* * *$ & & $*$ & & $* * *$ & \\
\hline
\end{tabular}

Önemlilik derecesi $\quad * * *$

\begin{tabular}{|c|c|c|c|c|c|c|c|}
\hline \multirow[b]{2}{*}{ Uygulamalar } & \multicolumn{2}{|c|}{ Sürgün kuru ağırlık } & \multicolumn{2}{|c|}{ Kök kuru ağırlık } & \multicolumn{2}{|c|}{ Toplam biyokütle } & \multirow{2}{*}{$\begin{array}{c}\text { Kök /Sürgün } \\
\text { oranı }\end{array}$} \\
\hline & $\mathrm{g} 100 \mathrm{~cm}^{-2}$ & Fark $(\%)$ & $\mathrm{g} 100 \mathrm{~cm}^{-2}$ & Fark $(\%)$ & $\mathrm{g} 100 \mathrm{~cm}^{-2}$ & Fark $(\%)$ & \\
\hline Azot & $4.91 \mathrm{a}$ & 69 & $30.03 \mathrm{a}$ & 131.3 & $34.94 \mathrm{a}$ & 120 & 6.1 \\
\hline MG-100 & $3.25 \mathrm{~b}$ & 11 & $19.28 \mathrm{c}$ & 48.5 & $22.53 \mathrm{c}$ & 42 & 5.9 \\
\hline MG-1000 & $3.10 \mathrm{bc}$ & 6 & $20.64 \mathrm{c}$ & 59.0 & $23.74 \mathrm{c}$ & 49 & 6.7 \\
\hline MG-2000 & $3.02 \mathrm{bc}$ & 4 & $25.58 \mathrm{~b}$ & 97.0 & $28.59 \mathrm{~b}$ & 80 & 8.5 \\
\hline \multirow[t]{2}{*}{ Kontrol } & $2.91 \mathrm{c}$ & -- & $12.98 \mathrm{~d}$ & 0.0 & $15.90 \mathrm{~d}$ & -- & 4.5 \\
\hline & 3.44 & & 21.7 & & & & \\
\hline Önemlilik Derecesi & $* * *$ & & $* * *$ & & $* *$ & & \\
\hline
\end{tabular}

Önemlilik Derecesi

***

önemlidir. $* * *$ ve $* * *$ sirasiyla $\mathrm{p} \leq 0.05, \mathrm{p} \leq 0.01$ ve $\mathrm{p} \leq 0.001$ düzeyinde önemli olduğunu ifade etmektedir. 
Çizelge 4. Azot $\left(10 \mathrm{~g} \mathrm{~N} \mathrm{~m}^{-2} \mathrm{yll}^{-1}\right)$, farklı dozlarda (100, 1000 ve $\left.2000 \mathrm{ml} \mathrm{m}^{-2}\right)$ mikrobiyal gübre (MG), ve kontrol $\left(0 \mathrm{ml} \mathrm{m} \mathrm{MG}^{-2} \mathrm{MG}^{0} \mathrm{~g} \mathrm{~N} \mathrm{~m}^{-2}\right)$ uygulamalarının Lolium perenne çiminin Sonbahar (Kasım 2013) ve İlkbaharda (Nisan 2014) yaprak besin elementi içerikleri üzerine etkileri.

Table 4. Effects of nitrogen (10 $\mathrm{g} \mathrm{N} \mathrm{m}^{-2}$ year-1), microbial fertilizer (MF) at different doses (MF 100,1000 and $2000 \mathrm{ml} \mathrm{m}^{-2}$ ) and control treatments (0 $\mathrm{ml} \mathrm{m}^{-2} \mathrm{MG}$ and $0 \mathrm{~g} \mathrm{~N} \mathrm{~m}^{-2}$ ) on leaf nutrient content of Lolium perenne in fall (November 2013) and Spring (April 2014).

\begin{tabular}{|c|c|c|c|c|c|c|}
\hline \multicolumn{7}{|c|}{ Sonbahar dönemi } \\
\hline \multirow[b]{2}{*}{ Besin elementleri } & \multicolumn{5}{|c|}{ Uygulamalar } & \multirow[b]{2}{*}{ Önem Derecesi } \\
\hline & AZOT & MG-100 & MG-1000 & MG-2000 & KONTROL & \\
\hline $\mathbf{N}(\%)$ & $5.95 \mathrm{a}$ & $4.18 \mathrm{~b}$ & $4.13 \mathrm{~b}$ & $3.98 \mathrm{~b}$ & $4.28 \mathrm{~b}$ & $* * *$ \\
\hline $\mathbf{P}(\%)$ & $0.42 \mathrm{a}$ & $0.37 \mathrm{a}$ & $0.38 \mathrm{a}$ & $0.30 \mathrm{~b}$ & $0.43 \mathrm{a}$ & $* *$ \\
\hline $\mathbf{K}(\%)$ & $3.04 \mathrm{a}$ & $2.64 \mathrm{bc}$ & $2.55 \mathrm{bc}$ & $2.41 \mathrm{c}$ & $2.78 \mathrm{ab}$ & $*$ \\
\hline $\mathrm{Ca}(\%)$ & $0.73 \mathrm{~b}$ & $0.83 \mathrm{ab}$ & $0.76 \mathrm{ab}$ & $0.89 \mathrm{a}$ & $0.87 \mathrm{a}$ & $*$ \\
\hline $\operatorname{Mg}(\%)$ & 0.17 & 0.15 & 0.15 & 0.15 & 0.17 & ÖD \\
\hline $\mathrm{Fe}(\mathrm{ppm})$ & $696.90 \mathrm{~b}$ & $810.23 \mathrm{~b}$ & $945.90 \mathrm{~b}$ & $1616.63 \mathrm{a}$ & $794.13 \mathrm{~b}$ & $*$ \\
\hline Zn (ppm) & $51.17 \mathrm{ab}$ & $46.07 \mathrm{bc}$ & $44.00 \mathrm{c}$ & $40.93 \mathrm{c}$ & $51.87 \mathrm{a}$ & $*$ \\
\hline Mn (ppm) & 61.27 & 68.53 & 70.37 & 69.83 & 74.73 & ÖD \\
\hline $\mathrm{Cu}(\mathbf{p p m})$ & $23.73 \mathrm{a}$ & $21.57 \mathrm{ab}$ & $17.93 \mathrm{c}$ & $19.60 \mathrm{bc}$ & $21.90 \mathrm{ab}$ & $*$ \\
\hline \multicolumn{7}{|c|}{ İlkbahar Dönemi } \\
\hline \multicolumn{7}{|c|}{ Uygulamalar } \\
\hline Besin elementleri & AZOT & MG-100 & MG-1000 & MG-2000 & KONTROL & Önem Derecesi \\
\hline $\mathbf{N}(\%)$ & $3.24 \mathrm{a}$ & $2.80 \mathrm{~b}$ & $2.70 \mathrm{~b}$ & $3.08 \mathrm{ab}$ & $2.70 \mathrm{~b}$ & $*$ \\
\hline $\mathbf{P}(\%)$ & 0.22 & 0.17 & 0.19 & 0.19 & 0.21 & ÖD \\
\hline $\mathbf{K}(\%)$ & $2.09 \mathrm{a}$ & $1.39 \mathrm{c}$ & $1.57 \mathrm{bc}$ & $1.73 \mathrm{~b}$ & $1.48 \mathrm{c}$ & $* *$ \\
\hline Ca $(\%)$ & 0.48 & 0.64 & 0.64 & 0.80 & 1.24 & ÖD \\
\hline $\operatorname{Mg}(\%)$ & 0.12 & 0.10 & 0.11 & 0.11 & 0.13 & ÖD \\
\hline $\mathrm{Fe}(\mathrm{ppm})$ & 848.37 & 925.77 & 837.27 & 850.77 & 1418.30 & ÖD \\
\hline Zn (ppm) & 31.44 & 25.81 & 26.86 & 27.49 & 52.37 & ÖD \\
\hline Mn (ppm) & 94.60 & 91.37 & 99.47 & 101.72 & 132.20 & ÖD \\
\hline $\mathrm{Cu}$ (ppm) & 4.79 & 4.52 & 4.80 & 4.92 & 5.94 & ÖD \\
\hline
\end{tabular}

, $\leq 0.01$ ve $p \leq 0.001$ düzeyinde önemli olduğunu ifade etmektedir. ÖD: Karşılaştırılan ortalamalar arasındaki farkların istatistiki olarak önemli olmadığını ifade etmektedir.

Araştırma sonuçları; mikrobiyal gübre ve azot uygulamalarının, çim yoğunluğu üzerindeki etkisinin istatistiksel olarak önemli olduğunu ortaya koymaktadır. Sonbaharda MG uygulamalarının tamamının azot ve kontrol parsellerine göre daha sik çim dokusu oluşturarak çim yoğunluğunu \%8 ile \%13 oranında arttırdıkları saptanmıştır (Çizelge 3). İlkbaharda ise en yüksek çim yoğunluğu kontrole göre $\% 53$ artış sağlayan $2000 \mathrm{ml} \mathrm{MG}$ uygulaması ile elde edilmiş ve yoğunluğu kontrole göre \%25-28 oranında arttıran diğer MG dozları ile N arasındaki farklar ise istatistiksel olarak önemli bulunmamıştır. L. perenne gibi çim türleri kardeşlenerek çim yoğunluğunu arttırmaktadırlar ve sitokinin hormonu kardeşlenmeyi teşvik eden temel bitki hormonudur (Langer ve ark. 1973; Ervin ve Zhang 2008; Liu ve ark. 2011). Oksin ise sitokinin biyosentezinden sorumlu genin (OsIPT) ekspresyonunu kontrol etmek suretiyle kardeşlenmeyi etkilemektedir. (Liu ve ark. 2011). Ayrıca sitokin gibi azotun da bitkide kardeşlenmeyi teşvik ettiği (Liu ve ark. 2011) ve optimum seviyede uygulandığında çim yoğunluğunu arttırdığ 1 bilinmektedir (Heydari ve Balestra 2008). Çalışmamızda kullanılan MG'nin çim yoğunluğunu arttırıcı etkisi, içerdiği bakterilerin sitokinin ve oksini üretebilme ve/veya modifiye edebilme yeteneğine ve ayrıca azot bağlayabilme özelliklerine bağlanabilir. Nitekim çalışmada kullandığımız Bacillus spp. ve $P$. aglomerans ve $P$. fluorescens bakterilerinin indol asetik asit ve sitokinin hormonlarını sentezleyebildiği bildirilmiştir (Pallai ve ark. 2012; Castanheira ve ark. 2013; Li ve ark. 2016).

Denemenin sonlandırıldığı tarihte ölçülen kök, sürgün ve toplam kuru ağırlık değerleri üzerinde gübre uygulamalarının etkisinin önemli olduğu ve $\mathrm{N}$ uygulamasının kontrole göre sürgün miktarında \%69 artış sağladığı belirlenmiştir (Çizelge 3). Sürgün kuru ağırlığını kontrole göre \%4-11 oranında arttıran MG uygulamaları arasındaki farklar ise önemli bulunmamıştır. Benzer şekilde içinde $B$. megaterium ve $P$. fluorescens ve Pantoea spp. türlerinden en az ikisini içeren mikrobiyal gübrelerin; bitki gelişimini teşvik ederek sürgün miktarını misirda \%39, Pennisetum purpureum bitkisinde \%70'e varan oranlarda arttırdığı bildirilmiştir (El-Enazy ve ark. 2017; Li ve ark. 2016). Sürgün kuru ağırlık sonuçlarına benzer şekilde en yüksek ve en düşük kök kuru ağırlık değerlerinin sırasıyla $\mathrm{N}$ ve kontrol parsellerinden elde edildiği ve $\mathrm{N}$ uygulamasının kök ağırlığını \%131 oranında arttırdığı anlaşılmıştır. Doz artışına paralel olarak kök biyomasını kontrole göre \%49-97 oranında arttıran MG dozları arasındaki farkların önemli olduğu tespit edilmiştir. Kök ve sürgün ağırlıkları beraberce değerlendirildiğinde; toplam biyokütle açısından kontrole göre en yüksek artış \%120 ile azot uygulamasında bulunmuş ve onu $\% 80$ ile $2000 \mathrm{ml} \mathrm{MG}$ uygulaması takip etmiştir. Mikrobiyal gübrelerin kullanımı sonucunda kök ve toplam biyokütlede artış C. dactylon çiminde de bildirilmiştir (Kuo 2015). Öte yandan Peacock ve Daniel (1992) F. arundinaceae ve $C$. dactylon çim türlerinde Bacillus spp uygulamasının üre azot kaynağ kullanılarak yapılan konvansiyonel gübrelemeye göre bitki büyüme ve gelişmesini artırmadığını bildirmişlerdir. Bu durum araştırıcıların çalışmalarındaki bakteri ve konukçu bitki uyumsuzluğundan ileri gelmiş olabilir. Nitekim mikrobiyal gübrelerin bitki büyüme ve gelişimi üzerine pozitif etkisi bitkibakteri türü uyumuna bağlı olduğundan hedef bitkiye uygun bakterilerin tespit edilmesi, izole edilmesi ve uygulanmasi önemlidir (Baldani ve ark. 1997). Lindberg ve Granhall (1984) 
çalışmamızda kullanılan Bacillus ve Pseudomonas cinslerinin varlığını $L$. perenne türünün doğal yetişme ortamındaki kök bölgesinden alınan örneklerde de tespit etmişlerdir. Benzer şekilde Castanheira ve ark. (2013) $L$. perenne ile akraba tür $L$. multiflorum çim türünün doğal yetiştiği ortamda tespit ettikleri faydalı bakteriler içinde $P$. Fluorescens, $P$. aglomerans ve bacillus spp. türlerinin olduğunu bildirmişlerdir. Sonuçlar MG uygulamalarının, sürgüne kıyasla özellikle kök büyüme ve gelişmesini daha fazla teşvik ettiğine işaret etmektedir. Nitekim kök/sürgün oranlarının $2000 \mathrm{ml}$ MG, Azot ve kontrol uygulamalarında sirasıyla $8.5,6.1$ ve 4.5 olduğu ve $M G$ dozu arttıkça kök/sürgün oranının arttığ 1 tespit edilmiştir. Öte yandan Kuo (2015) ise Rhizobium, Azotobacter, Cyanobacteria içeren MG uygulamasının $C$. dactylon çiminde kök/sürgün oranını arttırmadığını bildirmiştir. Bu durum iki çalışmada kullanılan bakterilerin ve kullanılan çim türlerinin farklı olmasından kaynaklanmış olabilir. Çalışmamızda MG uygulaması sonucu biyokütle ve özellikle kök gelişiminde sağlanan artışlar kullanılan rizosfer bakterilerinin hem gerekli olan bitki besin elementlerini biyolojik yolla yarayışlı hale getirmeleri hem de büyüme ve gelişmeyi teşvik eden fitohormonları sentezleyebilmeleri neticesi kök morfolojisi ve fizyolojisinde yaptıkları değişiklikler ile kök biyomasını ve dolayısıyla besin elementlerinin alınabilirliğini arttırmış olabilmeleri ile açılanabilir (Qasim ve ark. 2014; Steenhoudt ve Vanderleyden 2000). Nitekim çalıșmamızda kullanılan bakterilerin ürettikleri glukonik asit, sitrik asit ve oksalik asit gibi organik asitler ile inorganik fosfatı çözerek $\mathrm{P}$ alımını arttırdıkları, $\mathrm{N}$ bağlayabildikleri ve böylece verim artışı sağladıkları farklı araştırmacılar tarafından da belirlenmiştir (Castanheira ve ark. 2013; Al-Enazy ve ark. 2017; Li ve ark. 2016). Azot ve P yanında demirinde çim bitkilerinde kök gelişimini etkilediği ve azot ile birlikte verilmesinin kök kuru ağırlığını önemli ölçüde arttırdığı bildirilmiştir (Heydari ve Balestra 2008). Çalışmada kullandığımız bakterilerin demirin alınabilirliğini sağlayan siderefor üretiminde oldukça etkin oldukları kanıtlanmıştır (Li ve ark. 2016). Mikrobiyol gübre uygulamaları ile elde ettiğimiz artan kök/sürgün oranı aynı zamanda içeriğindeki Bacillus spp. ve $P$. aglomerans bakterilerinin oksin ve sitokinin gibi fitohormonları sentezleyebilme yetenekleri ile de açıklanabilir (Castanheira ve ark. 2013; Li ve ark. 2016). Nitekim köklendirme hormonu olarak bilinen oksin, bitkide sitokinin düzeyine bağlı olarak köklenmeyi teşvik etmekte ve kök gelişimini artırmaktadır (Davies 2010; Zhang ve ark. 2017; Taiz ve Zeiger 2010). Benzer şekilde sitokinin uygulamasının çim ve diğer monokot bitkilerde sürgün büyümesini teşvik ettiği, kök biyomasını arttırdığ 1 ve total biyokütleyi arttırdığ $\breve{g}_{\text {bildirilmiştir }}$ (Ervin ve Zhang 2008; Liu ve ark. 2002; Butler 2006; Zahir ve ark. 2001).

Bitki besin elementleri analiz sonuçları incelendiğinde; sonbaharda $\mathrm{Mg}$ ve $\mathrm{Mn}$ hariç diğer makro ve mikro besin elementleri açısından uygulamalar arasındaki farklar istatistiksel olarak önemli bulunmuştur (Çizelge 4). En yüksek toplam N içeriği \%5.95 ile azot uygulamasında tespit edilirken \%4.283.98 arasında varyasyon gösteren kontrol ve MG uygulamaları arasındaki farklar ise önemli bulunmamıştır. Yaprak P içeriği $2000 \mathrm{ml} \mathrm{MG}(\% 0.30)$ uygulamasında daha düşük bulunurken, diğer uygulamalar $(\% 0.37-0.43)$ arasında fark bulunmamıştır. En yüksek K içeriği \%3.04 ile azot uygulamasında bulunurken. $2000 \mathrm{ml}$ MG uygulaması hariç diğer MG ve kontrol uygulamaları istatistiksel olarak benzer $\mathrm{K}$ içeriği göstermişlerdir. En yüksek Fe içeriği 1616.6 ppm ile $2000 \mathrm{ml}$ MG uygulamasında bulunurken, diğer uygulamalar arasındaki farklar istatistiksel olarak önemli bulunmamıştır. Mikrobiyal gübre kullanımı sonucu artan Fe içeriğinin $B$. megaterium ve Pseudomonas bakterilerinin Li ve ark. (2016) ve Bloemberg ve Lugtenberg (2001) tarafindan kanitlandığ 1 üzere toprakta alınamaz formdaki demiri şelatlamak suretiyle demirin bitkiye alınabilmesini sağlayan sideroforları üretebilme özelliklerinden kaynaklandığı düşünülmektedir. Benzer şekilde MG uygulaması sonrası yaprak Fe konsantrasyonunda artış diğer araştırmacılar tarafindan da bildirilmiştir (Singh ve Shah 2013; Singh ve ark. 2017). En düşük yaprak $\mathrm{Cu}$ içeriğine sahip uygulamaların 17.919.6 ppm ile sirasıyla $1000 \mathrm{ml} \mathrm{MG} \mathrm{ve} 2000 \mathrm{ml}$ MG olduğu ve 23.7-21.6 ppm arasında $\mathrm{Cu}$ içeriğine sahip diğer uygulamalar arasındaki farkların ise önemli olmadığı tespit edilmiştir. AlEnazy ve ark. (2017) Misır bitkisinde benzer şekilde $B$. megaterium and $P$. fluorescens içeren MG gübre uygulaması sonrası ( 5 hafta) yaprak $\mathrm{Cu}$ içeriğinin kontrole göre daha düşük olduğunu bildirmiştir. Öte yandan araştırıcılar bu çalışmanın aksine mısırda $\mathrm{MG}$ uygulamasının $\mathrm{Fe}$ içeriğini düşürdüğünü bildirmiştir. En yüksek $\mathrm{Zn}$ içeriği sırasılyla kontrol ve azot uygulamalarında bulunmuş ve artan MG dozuna bağlı olarak Zn içeriğinin azaldığı tespit edilmiştir. Bu eğilim, ilkbahar dönemi yaprak analiz sonuçlarında da görülmüştür. MG uygulama dozuna bağlı olarak azalan $\mathrm{Zn}$ içeriği, çalışmamızda sürgün ve özellikle kök biokütlesini önemli ölçüde arttıran bakterilerin büyümeyi teşvik eden oksin üretimi için daha fazla $\mathrm{Zn}$ kullanımından ileri gelmiş olabilir. Bilindiği üzere $\mathrm{Zn}$ oksinin (IAA) hammaddesi olan triptofan amino asitinin sentezi için gerekli olan mikro besin elementidir (Brown ve ark. 1993; Alloway 2004; Skoog 1940). İlkbahar döneminde N ve K hariç besin elementleri açısından uygulamalar arası farklar önemli bulunmamıştır (Çizelge 4). Azot ve $2000 \mathrm{ml}$ MG uygulamalarının İlkbaharda ort. \%3.1 ile diğer uygulamalardan daha yüksek $\mathrm{N}$ içeriğine sahip oldukları tespit edilmiştir. En yüksek K içeriği \%.2.09 ile azot uygulaması ile elde edilirken, $2000 \mathrm{ml} \mathrm{MG}$ uygulaması \%1.73 ile onu takip ederek diğer uygulamaları geride bırakmıştır. MG uygulaması sonucu kontrole göre yaprak $\mathrm{N}$ ve $\mathrm{K}$ oranlarındaki artış Al-Enazy ve ark. (2017) ile uyum içindedir. Özellikle $2000 \mathrm{ml}$ MG uygulamasının kontrolden daha fazla $\mathrm{N}$ ve $\mathrm{K}$ içermesi, içerdiği bakterilerin $\mathrm{N}$ bağlaması ve artan kök yüzey alanı sayesinde daha fazla besin elementlerine ulaşımı ile ilgili olabilir. Nitekim 2000 ml MG kontrole göre kök biokütlesini önemli ölçüde arttırmıştır.

\section{Sonuç}

Çalışmada kullanılan MG; L. perenne türünün tesis olma hızını, çim kalite ve rengini, çim indeks değerini, çim yoğunluğunu ve kök/sürgün oranını kontrole göre arttırmıştır. Genel olarak MG dozu arttıkça genel çim performansında artış gözlemlenmiştir. Çalışmada en yüksek kalite ve koyu renk konvansiyonel gübre uygulaması ile elde edilmiştir. Yüksek doz MG $\left(2000 \mathrm{ml} \mathrm{m}^{-2}\right)$ ise azot uygulamasına eşdeğer hızla alanda tesis olmuş üstelik daha sık çim dokusu oluşturmuştur. Ayrıca yüksek doz MG uygulamasının kabul edilebilir ve üstü bir çim kalitesi sağlarken, biçim artıklarını konvansiyonel azot uygulamasına göre önemli ölçüde baskıladığı ortaya konulmuştur. Bu durum biçim sıklığını azaltacağından dolayı biçim masrafinı düşürebilir ve az olan biçim sonrası artıklarının toplanmak yerine alan üzerine bırakılmasına imkan sağlayabilir. $\mathrm{Bu}$ sayede, hem besin elementlerinin geri dönüşümü hem de çöpe gidecek atık maddelerin miktarının azaltılması ve biçim masraflarının düşürülmesi ile sürdürülebilir çim alan yönetimi sağlanabilir. 
Çalışma, kaliteli ve sürdürülebilir yeşil alan yönetimi için mikrobiyal gübrelerin kimyasal gübrelerin kullanımını azaltabileceği ve/veya onlara alternatif olabileceğine işaret etmektedir. Öte yandan daha yüksek çim kalitesinin beklendiği ve/veya farklı stresler sonrası hızlı bir rejenerasyon yeteneğinin (sürgün gelişiminin) istendiği durumlar için mikrobiyal gübrenin düşük doz azotlu gübreler ile birlikte etkisi araştırılmalıdır. Ayrıca mikrobiyal gübrenin diğer çim türleri üzerindeki etkilerinin araştırılmasının yerinde olacağı sonucuna varılmıştır.

\section{Kaynaklar}

Aamlid TS, Andersen TE, Kvalbein A, Pettersen T, Jensen AD (2014) Composted garden waste as organic amendment to the USGARootzone and topdressing Sand on Red Fescue (Festuca rubra). Greens 79(3): 87-96.

Açıkgoz E, Bilgili U, Sahin F, Guillard K (2016) Effect of plant growthpromoting Bacillus sp. on color and clipping yield of three turfgrass species. Journal of Plant Nutrition 39(10): 1404-1411.

Al-Enazy A, Al-Oud SS, Al-Barakah FN, Usman AR (2017) Role of microbial inoculation and industrial by-product phoshogypsum in growth and nutrient uptake of maize (zea mays L.) grown in calcareous soil. J Sci Food Agric. 97: 3665-3674.

Alloway BJ (2004) Zinc in Soils and Crop Nutrition.Publ. of International Zinc association. http://www.iza.com/Documents/Communications/Publications/AL LOWAY_PRINT.pdf. Accessed 4 October 2010.

Baldani JI, Caruso L, Baldani VLD, Goi SR. Döbereiner J (1997) Recent advance in BNF with non-legume plant. Soil Biol Biochem 29: 911-922.

Beard JB (1973) Turfgrass: Science and Culture. Prentice-Hall. Inc. NY.

Bloemberg GV, Lugtenberg BJJ (2001) Molecular basis of plant growth promotion and biocontrol by rhizobacteria. Curr. Opin. Plant Biol. 4: 343-350.

Butler T (2006) Plant hormones in Turfgrass Management. Pitch care. https://www.pitchcare.com/news-media/plant-hormones-inturfgrass-management.html.

Brown PH, Cakmak I, Zhang Q (1993) Form and function of zinc in plants. Chap. 7. In A.D. Robson (Ed). Zinc in Soils and Plants. Kluwer Academic Publishers. Dordrecht. pp. 90-106.

Castanheira N, Dourado AC, Alves PI, Cortes-Pallero AM, DelgadoRodriguez AI, Prazeres A, Borges N, Sanchez C, Crespo MTB, Fareleira P (2013) Annual ryegrass-associated bacteria with potential for plant growth promotion. Microbiological Research. 169: 768-779.

Çakmakçi R, Kantar F, Algur ÖF (1999) Sugar beet and Barley Yields in relation to Bacillus polymyxa and Bacillus megaterium var. phospaticum inoculation. J. Plant Nutr. Soil Sci. 162: 437-442.

EEA (2009) Water resources across Europe: Confronting water scarcity and drought. Environ. Agency. Copenhagen. http://www.eea.europa.eu/publications/water-resources-acrosseurope. Accessed 10 March 2019.

Emmons R (2000) Turfgrass Science and Management. Delmar Publishers. Albany. NY.

Ervin EH, Zhang X (2008) Applied physiology of Natural and Synthetic Plant Growth Regulators on Turfgrass. In M. Pessarakli ed. Handbook of turfgrass management and physiology. CRC Press. Boca Raton. FL. pp. 690.

Davies PJ (2010) Plant hormones: Biosynthesis, signal trans-duction, action 3rd ed. Springer. New York. DOİ: 10.1007/978-1-40202686-7.

Ding YF, Huang PS, Ling QH (1995) Relationship between emergence of tiller and nirogen concentration of leaf blade or leaf sheath on specific node of rice. J Nanjing Agric Univ 18: 14-18 (in Chinese with English abstract).

EU (2009) Directive 2009/128/EC of the European Parliament and of the Council of 21 October 2009 on establishing a framework for Community action to achieve a sustainable use of pesticides. Off. J. Europ. Union L.309/71.

Feng Y, Shen D, Song W (2006) Rice endophyte Pantoea agglomerans YS19 promotes host plant growth and affects allocations of host photosynthates. J Appl Microbiol 100: 938-45.

Flipse WJ. Katz BG. Lindner JB. Markel R (1984). Sources of nitrate in groundwater in a sewered housing development. Central Long Island, New York. Ground Water 32: 418-426.

Guillard K, Kopp KL (2004) Nitrogen fertilizer form and associated nitrate leaching from cool-season lawn turf. J. Environ. Qual. 33: 1822-1827.

Javorekova S, Makova J, Medo J, Kovacsova S, Charousova I, Horak J (2015) Effect of bio-fertilizers application on microbial diversity and physiological profiling of microorganisms in arable soil. Eurasian Journal of Soil Science 4: 54-61.

Heckman JR, Liu H, Hill W, DeMilla M, Anastasia WL (2000). Kentucky bluegrass responses to mowing practices and Nitrogen Fertility Management. Journal of Sustainable Agriculture 15(4): 2533. https://doi.org/10.1300/J064v15n04_04.

Heydari A, Balestra GM (2008). Nutritional Disorders of Turfgrasses. In: Handbook of Turfgrass Management and Physiology (M Pessarakli. ed). CRC Press Taylor \& Francis Group. Boca Raton, pp. 211-221.

Jayaswal RK, Fernandez M, Upadhyay RS, Visintin L, Kurz M, Webb J, Rinehart K (1993) Antagonism of Pseudomonas cepacia against phytopathogenic fungi. Curr. Microbiol. 26: 17-22.

Kacar B. İnal A (2008) Bitki Analizleri. Nobel Yayın Dağıtım. Ankara.

Kloepper JW, Schippers B, Bakker PAHM (1992) Proposed elimination of the term endorhizosphere. Phytopathol 82: 726-727.

Kuo Y (2015) Effects of fertilizer type on chlorophyll content and plant biomass in common bermudagrass. African Journal of Agricultural Research 10(42): 3997-4000.

Langer RHM, Prasad PC, Laude HM (1973) Effects of kinetin in tiller bud elongation in wheat (Triticum aestivum L). Ann Bot. 37: 565571.

Ledeboer FB, Skogley CR (1973) Effects of various nitrogen sources. timing. and rates on quality and growth rate of cool-season turfgrasses. Agronomy Journal 65: 243-246.

Li X, Geng X, Xie R, Fu L, Jiang J, Gao L, Sun J (2016) The endophytic bacteria isolated from elephant grass (Pennisetum purpureum Schumach) promote plant growth and enhance salt tolerance of Hybrid Pennisetum. Biotechnol Biofuels 9: 190-213.

Lindberg T, Granhall U (1984) Isolation and characterization of dinitrogen-fixing bacteria from the rhizosphere of temperate cereals and forage grasses. Applied and Environmental Microbiology 48: 683-689.

Liu H, Hull RJ, Duff DT (1997) Comparing cultivars of three coolseason turfgrasses for soil water $\mathrm{NO}_{3}$ concentration and leaching potential. Crop Sci. 37: 526-534.

Liu X, Huang B, Banowetz G (2002) Cytokinin effects on Creeping bentrgrass responses to heat stress: I.Shoot and Root Growth. Crop Sci. 42: 457-465.

Liu Y, Gu D, Ding Y, Wang Q, Li G, Wang S (2011) The relationship between nitrogen auxin. and cytokinin in the growth regulation of rice (Oryza sativa L.) tiller buds. Australian Journal of Crop Science 5(8): 1019-1026.

Miltner ED, Stahnke GK, Johnston WJ, Golob CT (2004) Late fall and winter nitrogen fertilization and turfgrass in two pacific northwest climates. HortScience 39: 1745-1749. 
Miltner ED, Branham BE, Paul EA, Rieke RE (1996) Leaching and mass balance of $15 \mathrm{~N}$-labeled urea applied to a Kentucky bluegrass turf. Crop Sci. 36: 1427-1433.

Nektarios PA, Petrovic AM, Steenhuis TS (2014) Nitrate and Tracer leaching from aerated turfgrass profiles. European Journal of Horticultural Science 79: 150-157.

Nunes C, Usall J, Teixido N, Fons E, Vinas I (2002) Post-harvest biological control by Pantoea agglomerans (CPA-2) on Golden Delicious apples. J Appl Microbiol 92: 247-255.

Pallai R, Hynes RK, Verma B, Nelson LM (2012) Phytohormone production and colonization of canola (Brassica napus L.) roots by Pseudomonas fluorescens 6-8 under gnotobiotic conditions.Canadian Journal of Microbiology 58(2): 170-178. https://doi.org/10.1139/w11-120.

Parlak S, Güner D (2017) Mikrobiyal gübre uygulamasının karaçam (Pinus nigra Arnold. Subsp. Pallasiana (Lamb.) Holmboe) fidanlarının bazı morfolojik özelliklerine etkisi. Ormancılık Araştırma Dergisi 4(2): 100-106.

Parker JE (2003) Plant recognition of microbial patterns. Trends Plant Sci. 8: 245-247.

Peacock CH, Daniel PH (1992) A comparison of Turfgrass response to biologically amended Fertilizers. Hort Science 27(8): 883-884.

Ping L, Boland W (2004) Signals from the underground: bacterial volatiles promote growh in Arabidopsis. Trends Plant Sci. 9: 263266.

Parveen H, Singh AV, Khan A, Prasad B, Pareek N (2018). Influence of plant growth promoting rhizobacteria on seed germination and seedling vigor of green gram. Int. J Chemical Studies 6(4): 611618 .

Paulino-Paulino J, Harmsen EW, Sotomayor-Ramirez D, Rivera LE (2008) Nitrate leaching under different levels of irrigation for three turfgrasses in southern Puerto Rico. J. Agr. Univ. Puerto Rico. 92: 135-152.

Puhalla CJ, Krans JV, Goatley JM (2010) Sports Fields: Design. Construction and Maintenance. $2^{\text {nd }}$ Edition. Wiley. Hoboken. NJ.

Qasim M, Younis A, Zahir ZA, Riaz A, Raza H, Usman T (2014) Microbial inoculation increases the nutrient uptake efficiency for quality production of Gladiolus grandifloras. Pak J Agric. Sci. 51: 875-880.

Reddy CA Saravanan RS (2013) Polymicrobial multi-functional approach for enhancement of crop productivity. Adv. Appl. Microbiol. 82: 53-113. doi:10.1016/B978-0-12-407679-2.00003-X.

Ryu CM, Faraq MA, Hu CH, Reddy MS, Kloepper JW, Pare PW (2004) Bacterial volatiles induce systemic resistance in Arabidopsis. Plant Physiol. 134: 1017-1026.
Sakakibara H, Takei K, Hirose N (2006) Interactions between nitrogen and cytokinin in the regulation of metabolism and development. Trends Plant Sci. 11: 440-448.

Singh AV, Shah S (2013) Plant Growth-Promoting Rhizobacteria for Sustainable Agriculture. In: Modern technologies for sustainable agriculture. (Ed Kumar S. Prasad B). Modern Tech Sustainable Agri. New Delhi, India, pp. 151-168.

Singh J, Singh AV, Prasad B, Shah S (2017) Sustainable agriculture strategies of wheat biofortification through microorganisms. In: Wheat a premier food crop. (Ed. Anil Kumar. Amarjeet Kumar and Birendra Prasad). Kalyani. Publishers. New Delhi, India, pp. 373391.

Skoog F (1940) Relationship between zinc and auxin in the growth of higher plants. Am. J. Bot. 27: 939- 951.

Starr JL, DeReo HC (1981) The fate of nitrogen fertilizer applied to turfgrass.Crop Sci. 21: 531-536.

Steenhoudt O, Vanderleyden J (2000) Azospirillum: a free-living nitrogen-fixing bacterium closely associated with grasses: genetic, biochemical and ecological aspects. FEMS Microbiol. Rev. 24: $487-506$

Strandberg M, Blomback K, Dahl Jensen AM, Knox W (2012) Priorities for sustainable Turfgrass management: a researh and industry perspective. Acta Agriculturae Scandinavica Section BSoil and Plant Science 3: 1-7.

Taiz L, Zeiger E (2010) Auxin: The first discovered plant growth hormone. In: L. Taiz and E. Zeiger. Editors. Plant physi-ology. 5th ed. Sinauer Associates Inc. Publishers. Sunderland. MS. pp. 545582 .

Turgeon AJ (1998) Turfgrass Management. 5th ed. Prentice-Hall. Englewood Cliffs. NJ.

Van Duyne B (1994) The spring grass and leaf diet. BioCycle 35: 6162.

Vessey JK (2003) Plant growth promoting rhizobacteria as biofertilizers. Plant and Soil 255: 571-586.

Zahir ZA, Asghar HN, Arshad M (2001) Cytokinin and its precursors for improving growth and yield of rice. Soil Biol Biochem 33: 405408.

Zhang X, Ervin EH, Wu W, Sharma N, Hamill A (2017) Auxin and Trinexapac-ethyl impact on root viability and hormone metabolism in Creeping Bentgrass under water deficit. Crop Sci. 57: 1-8. doi:10.2135/cropsci2016.05.0434İ. 